\title{
ACQUISITION OF FOLK HEALING PRACTICES: A PHENOMENOLOGICAL STUDY GROUNDING THE EXPERIENCES OF PARASANTIGWAR IN CAGRARAY ISLAND, PHILIPPINES
}

\author{
MICHAEL B. BIBON, Ph. D. \\ Cawayan National High School, Bacacay, Albay, Philippines, 4509 \\ Department of Education-Albay Division \\ michael.bibon@deped.gov.ph \\ DOI: 10.47760/cognizance.2021.v01i08.002
}

\begin{abstract}
For many years, folk medicine has been the resort of many less privileged families who do not have access to modern health care facilities. A parasantigwar is a term coined to a folk healer in Cagraray island, Philippines, a native version of a doctor trained in traditional manner providing indigenous medicinal help in the locale. This study aimed to ground the lived experiences of these parasantigwar on their acquisition of folk healing skills. Phenomenology approach was conducted by immersion and interview to 8 identified parasantigwar through referral sampling technique. Result revealed that (1) apprenticeship to a folk healer in the family and (2) life setbacks of families were grounds which opted the parasantigwar to resort into traditional healing through cultural transmission and motivation by needs deficiency. This resulted to the parasantigwar's acquisition of practices through (1) passed knowledge and (2) aggregated learned skill. It was concluded that family plays an important role in the assimilation of the folk healing skill where this immediate environment is responsible for the transmission of the observed culture and development of motivation to suffice needs. Further studies need to be conducted to understand healing practices especially to the surrounding islands showing similarity in origins of folk healing practice.
\end{abstract}

Keywords: cagraray island, phenomenology, folk healer, lived experiences, parasantigwar, cultural anthropology

\section{Introduction}

Cagraray Island is located on the eastern coast of Bicol Region, Philippines with a population of approximately 69,000 based on the recent 2015 census. Most of its land mass is a sovereignty of Municipality of Bacacay connected by a bridge spanning on the narrowest portion of Sula channel (Bacacay, Albay Profile, n.d.). The immersion of Bibon (2021) in the locale revealed the abundance and reliance of its people to folk medicine brought by many shortcomings in the access to quality and modern health care system and facilities. Folk medicine has been the alternative for the majority especially for locals living in the isolated areas of Cagraray. Instead of buying expensive synthetic medicines, they resort to herbal concoctions and prayer-based therapies as prescribed by their native folk healers. Though accounts were documented on calling folk healers as parabulong referring to a generalist healer, oftentimes they were called as parasantigwar specifically pertaining to the ones performing healing rituals (Bibon, 2021). This culture of traditional healing was subjected to many challenges yet managed to survive compounding the foreign medical system and education brought by American occupation through globalization, and the cruel control of Spanish colonizers. In fact, these historical events of traditional healing brought significant 
blends of diverse practices of native and foreign healing arts, superstitions, beliefs and practices (Apostol and Baet, 2007).

According to Bibon (2021), the geographical location of the Cagraray island is one of the fundamental issues, along with poverty, which caused its people to rely on alternative medicine. Apart from a general shortage of personnel, the island residents' population has a wide range of illnesses for which even modern services are often not affordable and/or culturally irrelevant. These folk healers have supplemented the medicinal needs of less privileged people living in geographically isolated and disadvantaged areas (GIDA) where the traditional healing culture prevailed in the sub-communities of Cagraray island. The access to quality health care and medical professionals is often associated with power and capacity indicating benefited families having admittance in modern hospital facilities, while the poor is part of an estimated $50 \%$ who rely on the use of traditional healing practices administered by a folk healer (Gilani,2005). Therefore, the present study is significant in understanding the lived experiences of parasantigwar into the acquisition of their folk healing practices. This bridges the gap between cultural anthropology and dynamics of acquiring practices by understanding experiences.

\section{Literature Overview of Folk Healers' Origin of Experiences and Cultural Practice}

Folk healers were the ones called babaylans during the periods of colonization in the country until the establishment of the Republic of the Philippines. They are the "heads" of small communities who provide medical and moral assistance to their community subordinates (Aping, 2016). According to the annals of Asian travelers, folk healers and their indigenous healing in Philippines have been existing for thousands of years starting circa $8^{\text {th }}$ century. The rise of Catholicism in the country condemned folk healers as they were described as pagans and "works of evil". However, the practice is still dominant in isolated places with indigenous belief into deities and supernatural bodies (Saydoven, 2009). To present, many names have evolved to refer to folk healers. These include albularyo, manghihilot, medico, mangluluop, magtatawas and faith healers (Labastida, 2016).

In ancient Egypt, folk healers already existed though doctors during the time have already emerged. The growing complex society of ancient Egypt led to the development of medical research participated both by folk healers and the trained doctors (Brazier, 2018). Earliest beliefs already attributed bad luck and treatment to people in magic, gods, demons, and evil spirits. Practices of the folk healers steered towards the occurrence of its 6 categories (Aping, 2016) as: (1) psychic surgeons practicing surgery (Labastida, 2016); (2) healers using healing paraphernalia hovering it on the body of patient; (3) anointers, who rub saliva; (4) blowers, who blow on the infected area of patient; (5) whisperers, who deliver prayers on patient's affected area; and (6) psychic healers, who remotely treat patients. On the other hand, Mercado (1988) noted that prayers are symbols of holiness which were crucial part of healing practice requiring focus to communicate with the supernatural world.

Literature accounts on the origin of folk healing experiences revealed that it emerged from a family-line of folk healers while the skill is sharpened and acquired by years of apprenticeship (Apostol and Baet, 2007). In a study by Cerio (2015), he discovered that "self-discovery and experiences, dream and prophetic claims, and possessions" were the origins of folk healing practices accounting $25 \%$ of responses to self-discovery and experiences. This research shows congruence to the findings of Vrazinovski (1998), Pocs (1999), and Pocs (2005) who noted that folk healers have come in contact with supernatural 
forces and dreams in the course of their initial lives. In Serbia, the transfer of healing skill is initiated to a grandchild before age of 10 by a folk healer from a family (Zlatanovic, 1989). Gender also performs a significant role in folk healing. Petreska (2008) narrated citing the works of Obrembski where folk healers "could only be a woman who ceased to have a child and knows how to use charms and incantations". Petreska (2008) further cited that magic governs the transfer of folk healing knowledge through repetition of the charm taught by a folk healer to a female apprentice in three bridges in a Macedonian village. On the other hand, Cvetanovska (2002) stated that supernatural forces and healing prowess come close to people with physical deformities.

The consolidated body of literature directed an ample evidence on the diverse practices in folk healing with its origin on symbolizing kinship and heirloom in the family-line. This review of facts suggested that family is the center of origin of passed knowledge in folk healing where acquired practices were primarily rooted through apprenticeship.

\section{Theoretical Underpinnings of Cultural Practice Acquisition}

Culture plays a substantial role in the acquisition of skill in healing. This cultural transmission is brought by immediate environment where the person lives plus the need to perpetuate the culture since it is vital for their ways of survival (Taylor and Thoth, 2011). Further supported by Bronfenbrenner's (1979) bioecological systems theory, it emphasized the development of child from the interaction of various systems supporting its growth and development. Family, a microsystem, is one of the immediate environments which acts as a host bringing developmental expectations to the growing child, thus acquisition of a culture in the family. These theories presume that the culture of becoming a folk healer in the family is a passed knowledge and mastered through personal experiences.

The imitation of cultural information is not a consolidated knowledge or information acquired from random people. Wood et al. (2012) emphasized that knowledge acquisition is attained via selective mode to people who will serve as emulations. This theory underpins the supposition that acquisition of the cultural practice is primarily grounded on the immediate support system perceived as the "persons of emulation". In fact, the kin-based cultural transmission noted that extent of transmitting behavior often starts within proximity (Lamon et al., 2017) specifying family as origin of a learned behavior. These theories strengthen the role of family in the transmission of culture as models and raw sources of behavior. In the context of the study, the theory represents the transmission of the experiences of parasantigwar acquired from the observations in a folk healer in the family, and enhanced by individual capabilities.

\section{Objectives of the Study}

In this study, it digs down into the roots of folk healers' experiences and practices through immersion and interview. This phenomenology understands the nature of folk healers' lived experiences and how those acquired healing practices shaped them into becoming a folk healer. This was conducted by attaining the following specific research objectives:

(a) Determine the modes on the acquisition of folk healing practices of parasantigwar by venturing on their life experiences; and

(b) Ground the life experiences of parasantigwar in understanding their prevalence in the locale. 


\section{Research Methodology}

The study was conducted last 2019 in the Cagraray island, Philippines. The design is descriptive-qualitative, phenomenology research that makes use of methods like community immersion and interview in collecting data (Goldstein, 1964). The design and method were used to ground the lived experiences of 8 key informants ages 60 to 75 who were parasantigwar (folk healers) of Cagraray island practicing healing for more than 15 years. Identification of these parasantigwar was determined through referral sampling technique by interviewing locals of the island. A written consent was provided to the identified folk healers regarding data collection of their experiences and practices. The immersion and interview circulated on the lived experiences topics regarding their traditional healing practices and their acquisition of those practices which led them to undertake folk healing. Narratives were recorded in the vernacular yet translated to accommodate foreign readers. The translations in English were generated yet faithfully converted in relation to the context of the original text. Translations were reviewed by jurors and a set of evaluators to determine the consistency and validity from original narratives. For interpretative analysis, content analysis and ground theory were used to summarize and tabulate the data. This was done by coding the texts while utilizing axial coding to link the interconnected patterns in the content of narratives.

\section{Results and Discussion}

Locals recommended a total of ten (10) parasantigwar who were practicing folk healing for more than fifteen (15) years. Unfortunately, two (2) of them opted not to participate in the study in the belief that sharing their traditional healing practices is a violation to the spirits of nature. This cuts short the number of key informants into eight (8) successfully interviewed parasantigwar. The following narratives were the significant findings of the study

\section{A. Modes of Acquiring the Folk Healing Practice from Life Experiences}

Responses from the interviewed parasantigwar revealed that their life experiences paved to their training on becoming a folk healer. Primarily related to the passed knowledge from a folk healer in the family, others were shaped by personal experiences related to treating a sicked family member.

\section{A.1 Passed Knowledge}

Four (4) accounts from parasantigwar showed that their skill in folk healing is a knowledge acquired from a folk healer in the family who came before them. Experiences in learning were acquired through apprenticeship and observation of the processes in healing. This holds true to the literature of learning where acquisition of skills is primarily attributed to an immediate environment-the family (Roostin, 2018; Sequiera de Figueiredo and Dias, 2012). One narrative revealed that the passing of the skill comes with passing of an agimat (amulet), a paraphernalia described as portal to communicate with the supernatural world. According to Thwaite (2019) and Handloff (1982), amulets play an important function in folk healing as it is believed to provide good health. Accordingly, the use of amulets is believed to be an effective medium for communicating to the disturbed spirits which caused illness to a patient, hence amulets are a very good medium to seek for forgiveness in healing (Renato, 2003). The parasantigwar reiterated the methods on passing the amulet. Oftentimes, this is usually done when the original owner is about to pass away leaving the amulet to the next parasantigwar as heirloom through simple handing over of the paraphernalia. There are also accounts where the amulet is passed down to the next parasantigwar through swallowing a stone-like amulet which was coughed up by the owner on the moment of death. Stuart (n.d.) 
noted that swallowing of amulet in Philippines is common to blood kin stating that " $a$ pellet-like globule is coughed up into the receiver's hands or picked up and immediately taken and swallowed...delay or hesitation in its ingestion would cause this globule to just vanish and forever be lost". These amulets were first used during battles with the foreign colonizers as battle gear in the belief that its magical powers and spirituality will provide invincibility and protection from bullets (Stuart, n.d.). Therefore, ownership of the amulet symbolizes a parasantigwar who was designated to be the next folk healer in the family. Though the interviewed parasantigwar were not pronounced and obliged to follow the skill of folk healing, they intrinsically developed the skill based from the expectations of the locals, and with their willingness to help. These expectations were the assumptions of locals assuming that the apprentice have already mastered the craft of folk healing living with a parasantigwar in their family. Furthermore, the parasantigwar noted that the skill was not forced nor enforced. It gradually builds up with their continuous observations of the rituals done at their homes until such time that they were independently able to replicate the methods of healing. They have also cited that poverty caused them to stop schooling, and consider the skill of folk healing to provide financial support to their needs. In fact, recent study noted that $86 \%$ of folk healers were poor or came from a poor family (Cerio, 2020). All responses agreed that the most challenging aspect of learning the skill of a parasantigwar is providing the right herbal prescription. The fact that they have to deal with memorizing all the herbs for treating the illness, they also noted that most of the patients are not familiar of their herbal prescription which opted them to route on a more familiar yet effective herb. Nonetheless, the continuous practice of folk healing has soon developed their mastery of herbal prescription.

Based from the skill passed onto them, plates, candle, oil, ash, paper, holy palm, doll, altar, rosary, and in some cases, amulet were the summarized paraphernalia used in rituals for dealing with illnesses. True enough with existing literature, accounts from other folk healers of a nearby island also use the same paraphernalia to communicate with the healing spirits (Fernando and Fermin, 2008). The use of these materials was in different combination depending on the nature of the illness. One example is treating hudong (food poisoning) requiring, at least, the use of plates, oil, holy palm, and rosary with herbal prescription. For sorcery, doll, amulet, paper, ash, and rosary were at least used for the rituals. Accounts also showed that oil, ash, plates, and sometimes papers were all used for the ritual in treating patients believed to be sickened by a ungman/tawong lipod (see descriptions in Appendix).

Supernatural claims were also attributed to their identities. These parasantigwar have accounts on communicating and seeing spirits, deities, and The Virgin Mary to testify for their truthfulness in healing. As supported by the study of Berdon et al. (2016), folk healers accredit their healing abilities from their ancestors and apparitions while Lerman (1967) noted that the unusual connection of the folk healers to the spiritual world upholds the power to heal. They believe that these supernatural bodies protect and guide them in the process. Supernatural forces were also considered as sole sources of decision and use the parasantigwar to disseminate information. In fact, all parasantigwar believed that illnesses were brought by all these entities the patient has disturbed or accidentally come in contact with. "Moods" of these supernatural forces decide whether the parasantigwar has to go through with the healing session or to take rest.

Prayers are crucial for the healing of the patient. Traditional healing comes with prayers and meditation to communicate and seek forgiveness from the disturbed spirits (Andrade, 
2009). All interviewed parasantigwar have learned the skill of delivering orations and prayers. Sometimes, these orations were channelled books and novenas. Prayers were catholic-based usually starting with Ama Namin (Our Father) followed by self-made oration and incantations to communicate with supernatural bodies in treating the patient.

All these accounts from the parasantigwar have testified the fruitful body of acquired practices leading into becoming a folk healer. With the parasantigwar in the immediate family as the person of emulation, another folk healer emerges with the learned practices observed through apprenticeship. The inheritance of an amulet represents the legacy of folk healing that runs in the kinship of the family. Surprisingly, accounts in the decades-old literature of practices in folk healing and experiences showed parallelism to the present study implying the concrete preservation of the culture of traditional healing, not only in the Philippines but all throughout the world. Table 1 shows the summary of the practices and sociodemographic profile of the interviewed parasantigwar who learned the skill as a passed knowledge.

Table 1. Summary Matrix. Coding the profiles of parasantigwar who developed the folk healing practice as a passed knowledge.

\begin{tabular}{|c|c|c|c|c|}
\hline & $\begin{array}{c}\text { Parasantigwar } \\
1\end{array}$ & $\begin{array}{c}\text { Parasantigwar } \\
2\end{array}$ & $\begin{array}{c}\text { Parasantigwar } \\
3\end{array}$ & $\begin{array}{c}\text { Parasantigwar } \\
4\end{array}$ \\
\hline Gender & Female & Male & Female & Female \\
\hline Age & 61 & 73 & 65 & 61 \\
\hline Experience & 27 years & 32 years & 21 years & 22 years \\
\hline Religion & Catholic & Catholic & Catholic & Catholic \\
\hline Marital Status & Widowed & Married & Widowed & Widowed \\
\hline $\begin{array}{l}\text { Highest Level of } \\
\text { Education }\end{array}$ & $\begin{array}{l}\text { Not attended } \\
\text { school }\end{array}$ & $\begin{array}{l}\text { Elementary } \\
\text { Graduate }\end{array}$ & $\begin{array}{l}\text { Elementary } \\
\text { Graduate }\end{array}$ & $\begin{array}{l}\text { Grade } 5 \text { drop } \\
\text { out }\end{array}$ \\
\hline Healing Methods & $\begin{array}{l}\text { Rituals, herbal } \\
\text { treatment, } \\
\text { prayers }\end{array}$ & $\begin{array}{l}\text { Rituals, herbal } \\
\text { treatment, } \\
\text { prayers }\end{array}$ & $\begin{array}{l}\text { Rituals, } \\
\text { massage, } \\
\text { herbal } \\
\text { treatment, } \\
\text { prayers }\end{array}$ & $\begin{array}{l}\text { Rituals, } \\
\text { massage, } \\
\text { herbal } \\
\text { treatment, } \\
\text { prayers }\end{array}$ \\
\hline Paraphernalia & $\begin{array}{l}\text { Altar, paper, } \\
\text { doll, holy } \\
\text { palm, oil }\end{array}$ & $\begin{array}{l}\text { Amulet, altar, } \\
\text { rosary, oil, } \\
\text { ash, plates, } \\
\text { candles }\end{array}$ & $\begin{array}{l}\text { Altar, plates, } \\
\text { candles, oil, } \\
\text { ash, holy palm }\end{array}$ & $\begin{array}{l}\text { Rosary, paper, } \\
\text { oil, doll, holy } \\
\text { palm }\end{array}$ \\
\hline $\begin{array}{l}\text { Supernatural/spiri } \\
\text { tual beliefs* }\end{array}$ & $\begin{array}{l}\text { Tawong lipod, } \\
\text { dwende, } \\
\text { anab,karaw, } \\
\text { ungman }\end{array}$ & $\begin{array}{l}\text { Dwende, } \\
\text { karaw, } \\
\text { tawong lipod, } \\
\text { ungman, } \\
\text { anab, kapre }\end{array}$ & $\begin{array}{l}\text { Tawong lipod, } \\
\text { diablo, } \\
\text { enkanto, } \\
\text { karaw,anab }\end{array}$ & $\begin{array}{l}\text { Tawong lipod, } \\
\text { dwende, kapre, } \\
\text { engkanto }\end{array}$ \\
\hline Hours of work & $\begin{array}{l}\text { 9:00am-aftern } \\
\text { oon }\end{array}$ & Whole day & Whole day & Whole day \\
\hline $\begin{array}{l}\text { Acquisition of } \\
\text { ability to heal }\end{array}$ & $\begin{array}{l}\text { From her } \\
\text { mother }\end{array}$ & $\begin{array}{l}\text { From his } \\
\text { uncle }\end{array}$ & $\begin{array}{l}\text { From her } \\
\text { mother }\end{array}$ & $\begin{array}{l}\text { From his } \\
\text { father }\end{array}$ \\
\hline
\end{tabular}

*Descriptions in Appendix 
Through coding in Table 1, phenomenology of the parasantigwar revealed parallel similarity in their practices. Healing methods, paraphernalia, and belief in supernatural entities were found to contain major similarities suggesting a common origin of the practice. This can be attributed to close proximity of individuals in the area where skill adaptation and cultural transmission were vivid practices. In a study, Santoro and Albuquerque (2020) concluded that the vertical transmission of the medicinal healing is more predominant yet new information and practice will soon rise aggregately. This culture has been passed down from generations due to strong belief in supernatural bodies both by parasantigwar and the locals themselves. Significant paraphernalia were used as a form of communication tool to diagnose a patient. Nonetheless, differences in the responses were caused and improved by personal experiences which parasantigwar have assimilated from other distant folk healers and throughout years of practice.

\section{A.2 Aggregated Learned Skill}

First and foremost, these parasantigwar never expected that they will venture in folk medicine. The remaining four (4) narratives stated that life circumstances led them to become a folk healer. Dealing with the content of their narratives revealed that their personal experiences in probing and practicing folk healing developed their mastery of the skill. Similarity revealed across narratives that attempt to do healing is through helping a family member suffering from an illness. On herbal recommendations, their healing attempt is based from the prescriptions they heard from neighborhoods who have also experienced and successfully treated the same illness. Other forms of treatment were observed by them through visiting a parasantigwar thus, a typical local becomes a learned folk healer. This is supported by the study of Fouad et al. (2015) who revealed that family influences the career decision- and selection-making of its members on obligation, volition, work values, and engagement.

Grounding their similarities revealed that motivation to save a sick family member has initiated their first steps in learning the skill of folk healing. One aspect similar to all these parasantigwar is the experienced poverty causing them to resort on herbal concoctions in stead of accessing to quality healthcare facilities, in addition to their location isolation. This finding supports the existing literature particularly by Goldberg (2013) and Field (2019) on impoverished families relying on folk medicine. The data indicated that poverty is a strong predictor to drive people in isolated areas to resort on or become a parasantigwar.

Unlike the parasantigwar who acquired the skill through passed knowledge, these type of folk healers basically use and practice betel nut chewing, novena, altar, and rosary in their healing session plus the recommendation of herbal treatment. The focus of healing is the conduct of prayers where rituals were minimal. The rituals were initially done through praying by the novena and rosary to the patient. The same methods of prayer-based healing were documented in a study conducted by Larsen et al. (2018) and Peprah et al. (2018). For the parasantigwar, performing rituals were the most difficult aspect of healing because it requires focus to coordinate with spirits. Their chewed betel nut is used as topical smear to the affected areas of the illness or applied to hair whorl. As a matter of fact, $10 \%$ of the world's population is known to chew betel nut mostly in South, Southeast Asia, and Africa known as a cultural identifier and a learned behavior (Murphy et al., 2015). Moreover, these parasantigwar personally improve their learning through trial-and-error process of their herbal recommendations and based from the accounts of their clients. This practice is in accordance to Santoro and Albuquerque (2020) who noted that cultural transmission is 
aggregated and improved through years of practice. The conduct of rituals was primarily related to asking forgiveness to deities and spirits who were disturbed by their patients. Deities, spirits, saints, and gods were worshiped but no claims that they have seen apparitions. Just like other parasantigwar, they also believe that illnesses were caused by spirits which were disturbed by patients to deliver punishment and castigation. They honestly claimed that their healing is limited. They refer illnesses caused by sorcery and possession to parasantigwar with amulets (passed knowledge). Two (2) responses cited that improper intervention of a parasantigwar in treating sorcery-related conditions might result to bouncing back of the illnesses to the parasantigwar or to the folk healers' family members. They also specified that parasantigwar with amulets are capable of treating illnesses caused by sorcery because their paraphernalia serves as protection from the rebound of sorcery effects. This statement shows congruence to the ones cited by Stuart (n.d.) who documented that amulets serve protection to its carrier as the paraphernalia were previously used in battle field during colonization to provide safety against bullets. Dreadful as it seems for their love of the family, these parasantigwar opted not to deal with these illnesses caused by black magic. Table 2 summarizes the sociodemographic profile and practices of the interviewed parasantigwar from the aggregation and reinforcement of personal experiences.

Table 2. Summary Matrix. Coding the profiles of parasantigwar who developed the folk healing practice as reinforced and aggregated personal experiences.

\begin{tabular}{|c|c|c|c|c|}
\hline & $\begin{array}{c}\text { Parasantigwar } \\
5\end{array}$ & $\begin{array}{c}\text { Parasantigwar } \\
6\end{array}$ & $\begin{array}{c}\text { Parasantigwar } \\
7\end{array}$ & $\begin{array}{c}\text { Parasantigwar } \\
8\end{array}$ \\
\hline Gender & Female & Female & Female & Male \\
\hline Age & 60 & 75 & 62 & 61 \\
\hline Experience & 20 years & 36 years & 25 years & 25 years \\
\hline Religion & Catholic & Catholic & Catholic & Catholic \\
\hline Marital Status & Married & Widowed & Married & Married \\
\hline $\begin{array}{l}\text { Highest Level of } \\
\text { Education }\end{array}$ & $\begin{array}{l}\text { Elementary } \\
\text { Graduate }\end{array}$ & Grade 3 & Grade 2 & $\begin{array}{l}\text { High school } \\
\text { Graduate }\end{array}$ \\
\hline Healing Methods & $\begin{array}{l}\text { Rituals, } \\
\text { massage, herbal } \\
\text { prescription }\end{array}$ & $\begin{array}{l}\text { Rituals, } \\
\text { massage, } \\
\text { herbal } \\
\text { prescription }\end{array}$ & $\begin{array}{l}\text { Rituals, } \\
\text { massage, } \\
\text { herbal } \\
\text { prescription }\end{array}$ & $\begin{array}{l}\text { Rituals, } \\
\text { massage, } \\
\text { herbal } \\
\text { prescription }\end{array}$ \\
\hline Paraphernalia & $\begin{array}{l}\text { Altar, novena, } \\
\text { ugbas, rosaryo }\end{array}$ & $\begin{array}{l}\text { Altar, rosaryo, } \\
\text { novena }\end{array}$ & Altar, rosaryo & $\begin{array}{l}\text { Altar, ugbas, } \\
\text { rosaryo }\end{array}$ \\
\hline $\begin{array}{l}\text { Supernatural/spiritu } \\
\text { al beliefs* }\end{array}$ & $\begin{array}{l}\text { Tawong lipod, } \\
\text { anab, karaw }\end{array}$ & $\begin{array}{l}\text { Tawong lipod, } \\
\text { anab, karaw, } \\
\text { engkanto }\end{array}$ & $\begin{array}{l}\text { Tawong lipod, } \\
\text { karaw }\end{array}$ & $\begin{array}{l}\text { Tawong lipod, } \\
\text { anab, karaw, } \\
\text { engkanto }\end{array}$ \\
\hline Hours of Work & Whole day & Whole day & Whole day & Whole day \\
\hline $\begin{array}{l}\text { Acquisition of } \\
\text { ability to heal }\end{array}$ & $\begin{array}{l}\text { Consolidated } \\
\text { recommendation } \\
\text { from } \\
\text { neighborhoods } \\
\text { and other folk } \\
\text { healers. }\end{array}$ & $\begin{array}{l}\text { Consolidated } \\
\text { recommendati } \\
\text { on from } \\
\text { neighborhoods } \\
\text { and other folk } \\
\text { healers }\end{array}$ & $\begin{array}{l}\text { Consolidated } \\
\text { recommendati } \\
\text { on from } \\
\text { neighborhoods } \\
\text { and other folk } \\
\text { healers. }\end{array}$ & $\begin{array}{l}\text { Consolidated } \\
\text { recommendati } \\
\text { on from } \\
\text { neighborhoods } \\
\text { and other folk } \\
\text { healers. }\end{array}$ \\
\hline
\end{tabular}




\begin{tabular}{lll}
\hline Incorporated & Incorporated & Incorporated \\
with some & with some & with some \\
personal & personal & personal \\
discoveries & discoveries & discoveries \\
through & through & through \\
trial-and-error & trial-and-error & trial-and-error \\
process & process & process \\
\hline
\end{tabular}

* Descriptions in Appendix

For this type of parasantigwar, they believe that prayer is the most effective tool towards healing. Contrary to the parasantigwar who learned the knowledge through apprenticeship, these kind of parasantigwar were experts in herbal medications even on the start of their folk healing career. Their healing practice became sophisticated by adding up prayers and rituals which they have acquired from other folk healers in the locale. Their prayers were also based on Catholicism beginning with Ama Namin (Our Father) followed by intricate healing requests and incantations to spirits and deities. Faith and repentance of sins were the most powerful calls for spirits to grant forgiveness. Using paraphernalia like rosary and novena, they communicate with the spiritual world to heal the illnesses.

Responses shown in table revealed similarity in the codes of practices particularly in the use of paraphernalia and the type of healing methods employed by the parasantigwar. The paraphernalia used were similar to other parasantigwar (passed knowledge) yet tools were limited. This manifested the correspondence of response by these parasantigwar where serious conditions caused by sorcery were simply recommended to other parasantigwar (passed knowledge) who has the complete paraphernalia for the healing method. There was also a distinct evidence on the belief of spirits related to that of parasantigwar who acquired practices through passed knowledge. Nevertheless, accounts from these parasantigwar suggested the need to sustain family health needs due to poverty and lack of access to quality health care leading to their acquisition of practices and skills on becoming a folk healer. This result is supported by the findings of the study by Cerio (2020) who revealed that majority of folk healers experience poverty.

\section{B. Sample Lived Experiences of Parasantigwar in Cagraray Island: The Narratives}

The following narratives were the recorded accounts of parasantigwar in Cagraray island regarding their lived experiences toward becoming a folk healer. Snippets were also included to provide support to their experiences.

\section{B.1. Passed Knowledge: Parasantigwar 2}

Everything started when parasantigwar 2 was visited, through his dreams for 3 consecutive nights by his deceased uncle who was a parasantigwar. He noted how his uncle wanted him to continue the legacy of being a folk healer through owning his "Agimat" (amulet).

"Siguro kaya ako ang napili kang tiyuon ko ta ako kaito ang nagpapara-iba saiya kang buhay pa siya...Halos tuom ko na ang mga pambulong niya buda pangadyi ta ako kaito tigsusugo niya magtultog kang mga ibulong niyang masitas"

"Maybe I was chosen by uncle because I always go with him when he is still alive... I almost memorized all his medications and 


\section{prayers because he would always instruct me to pound his medicinal plants" (Author's translation)}

He further noted that his expertise in treating illnesses was a product of his observation to his uncle Tiyo Pansyo, the parasantigwar, prescribing herbal preparations, massage and runs rituals. His apprenticeship molded him into a well-refined folk healer through a calling from his uncle who passed away due to a suspected lung infection. Aside from his prescriptions of indigenous medicines, he also practiced massage to pregnant women, flu, numbness of muscles and bone fractures. Another healing practice he performs was through execution of rituals and incantations where the amulet he inherited was used in remedying sorcery and possession.

"Gift but tiresome" (Author's translation) as how he described himself as a folk healer. Given the fact that he has a farm to supervise, he also did home servicing for treating patients who cannot personally visit his altar. Oftentimes, he would be called from farm to assist a patient with urgent medication. "Medicines are everywhere. You just have to find them" (Author's translation). Based from his acquired practices, he used amulet, rosary, oil, ash, plates and candles through practices of rituals, herbal treatment, and prayers. "Not all illnesses can be cured by medicinal plants" (Author's translation) he exclaimed putting emphasis on the role of rituals as the alternative practice for healing. For 32 years serving the community as a parasantigwar, he has been practicing simultaneously his expertise in herbal prescription, massage, rituals, and prayers. He said that his life as a parasantigwar was like hitting two birds with one stone. As he helped people cure illnesses, he also earned good amount of money which he believed enough to provide support to their basic commodities at home. Though he lived with his wife and one grandson, it was his aspiration to provide his family their emotional, guidance and financial support especially to his 3 married children who were living in the mainland with their own families. He further noted that he used his skill in prayer-based treatment to ask spirits and deities for the safety of his family, and his patients as well.

Still working at 73 , his children were impeding him to work as parasantigwar. He argued that his calling as a folk healer is a mission he has to carry throughout his life. "If I am to stop this, who shall continue to do this?"(Author's translation), referring to healing as a mission that he must continue.

\section{B.2. Aggregated Learned Skill: Parasantigwar 6}

The sudden death of her husband 4 years after their marriage left her with the full responsibility to raise and nourish their two sons. It was her younger years that taught her the experiences leading to her acquisition of folk healing skills. "One of my sons is sickly" (Author's translation) she narrated suspecting hudong (food poisoning) as the primary cause of the son's illnesses. She further stated how a folk healer diagnosed his son for such cause acquired during fiesta.

"Muyahon kang aki kong makipyesta. Nagpuon sana ito sa kulog kang tulak kang hali siya sa pyestahan sa *** hanggang kung anu-ano na ang namatian niya" 
"My son likes going to fiestas. It started with stomachache he felt from a fiesta in *** until it leads to many different illnesses that hit him" (Author's translation)

For 2 years, her son suffered many illnesses including stomach ache, headache, unexplained muscle cramps on the stomach, pain on chest, shortness of breath, weakness and vomiting. Due to financial constraints, she relied on folk healers who have recommended her the use of many medicinal plants for treating each of the illness experienced by her son through kinilkig (herbal mixture) and rituals. "I went to all folk healers and find the prescribed medicines to cure my son" (Author's translation) she stated with the motivation that drove her for the survival of his son. She aspired nothing but the complete healing and good health of her family. After years of praying for son's health, her son passed away from a deep sleep.

These experiences in life left her bittersweet significant markings that changed her perspective on how she can use her knowledge in helping others. On a positive side, the death of her son brought her the learnings on how certain illnesses can be cured, and how these learnings can help her earn money. She has also adapted many practices from other folk healers and neighborhoods who taught her to treat many different conditions when she was seeking cure for her son's conditions. She is using altar, novena and rosary as paraphernalia for treating many conditions through massage, rituals, and herbal treatment.

Sorcery, sins, and disruption of tawong lipod, anab, karaw, engkanto (see Appendix) were the common root causes of illnesses as she stated; "Everything starts with undesirable treatment to others" (Author's translation). Reliance to folk healers was also described by her as "natural occurrence" due to fear and financial crisis preferring parasantigwar than learned doctors.

"Libangan ko na ang pagbulong. Ini na ang tiggigibo ko puon kang nagadan ang aki ko. Dahil sa mga naukdan kong pamulong sa aki ko hali sa mga parasantigwar, nakaukod naman akong mangbulong ki mga hilang"

"Healing became my hobby. This was my past time when my son died. From what I have learned from healing my son and from the practices of other folk healers, I have learned the cure to illnesses" (Author's translation)

After all the learning she acquired in the field, she officially called herself a parasantigwar at her late thirties. She described herself as "strong" for being able to surpass all life struggles and made use of those past experiences to help others. "I know how it feels for a parent with a sick son" (Author's translation) she narrated as one of the factors why she loved her job as a folk healer despite bringing many melancholic memories.

Working for 36 years as a parasantigwar, she believed that learning medicinal plants was a continuous endeavor for the growth of a folk healer. "You should learn something new to provide help to those with sickness" (Author's translation) giving premium to the importance of progression of knowledge in healing. Unlike some folk healers in nearby barangays, they noted that she is easy to approach and always ready to help. She further noted that schooling 
was never meant for her as she was dropped by her mother in grade 3 to buy and sell fish in fish docks.

Now that she is 75 years old, she narrated that her life's routine has never changed. As long as she and her remaining son were in good condition, she worried nothing but the bonding and good health for both of them.

\section{Grounding the Experiences and Practices in Understanding the Parasantigwar's Prevalence in the Locale}

The accounts from the interviewed parasantigwar led to the grounding of acquired experiences into two important concepts which mold them into becoming a folk healer; the (1) cultural transmission: and the (2) needs theory of motivation.

The parasantigwar, who learned the skill of folk healing as a passed knowledge, have acquired the learning through apprenticeship to a folk healer in the family. Accounts have also noted similarity on the transmission of an amulet which serves as a cultural identifier of the healing practice. These experiences on becoming a folk healer suggested that cultural learning is apparent with proximity to its practitioners piloting cultural transmission through observation. These parasantigwar affirm to the working theoretical underpinnings of the current study. According to Chang et al. (2010), cultural learning becomes eminent within a society where culture is passed down to its people. This form of learning rooted from cultural evolution where people teach and imitate information/practices as a form of social transmission (Richerson, 2005). This cultural transmission of the folk healing practices has been unintentionally passed to its immediate family members due to observation and immediacy through apprenticeship. This argues that the idea of apprenticeship to a practitioner is a smooth and powerful means to adapt and learn the culture of traditional healing skill. In fact, Guile and Young (2011) noted that apprenticeship is a mode for knowledge and practice acquisition, and as a basis for social learning. On the other hand, the parasantigwar who acquired the traditional healing skill through aggregation of learned experiences was internally driven by the desire to help an immediate family member. The life setbacks limited them to gain access to quality health care facilities which resulted in their motivation to depend on their possible means of healing- the traditional medicine. According to Maslow, needs create tensions internally which drive a person to alter his behavior in fulfillment of the needs (Hartzell, 2019). Deficiency needs evolve when people were deprived of their basic needs resulting to motivation. This motivation becomes stronger when the deficiency endures and the needs were unmet (McLeod, 2020). This proves that the desire of the parasantigwar were caused by the need to provide immediate medical help to a family member experiencing sickness due to the deficiency in quality healthcare facility or lack of opportunity due to financial crisis. This motivated the parasantigwar to learn and rely on alternatives to suffice the experienced family deficiencies particularly in health. Therefore, setbacks and deficiencies in access to medical facilities were strong ground to motivate the folk healer to acquire knowledge and rely on folk healing leading to the acquisition of the healing practices.

Figure 1 shows the grounding of the lived experiences of the parasantigwar on the acquisition of their folk healing practices from life experiences 


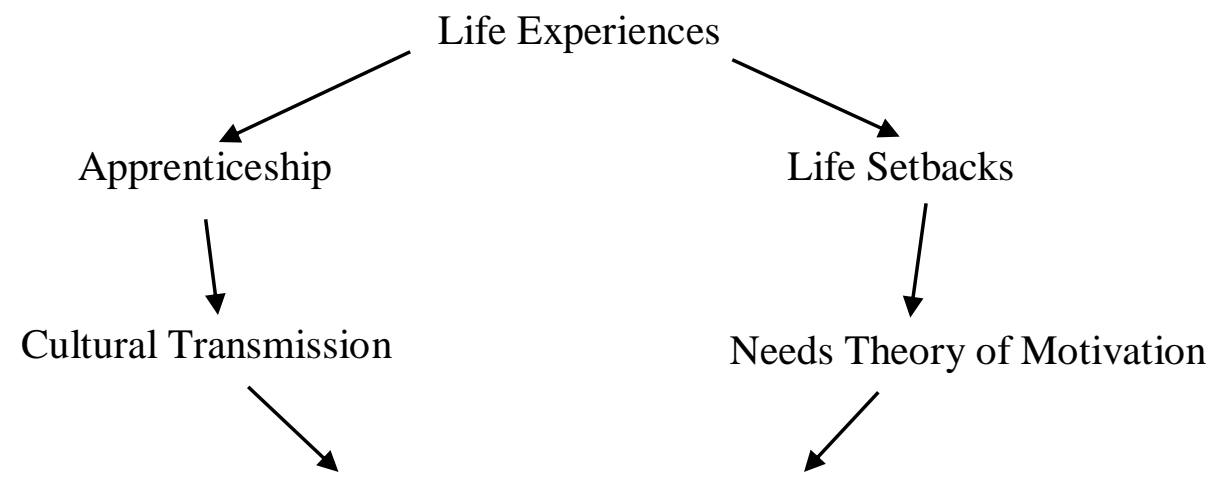

Acquisition of Folk Healing Practices

Figure 1. The life experiences and its modal grounds on the acquisition of folk healing practices of a parasantigwar.

The grounding of the life experiences of the parasantigwar is a clear sign that its prevalence runs in the culture of the locale following the transmission of this practice in the family. With the advent of contemporary medicine in the modern world, the isolation of the locale has preserved the practice through years, and was embedded in their identity. Undocumented in the preceding studies was the origin of a folk healing practice due to experienced life setbacks. This study documents and reveals that shortcomings were also contributory factors in the learning of a practice, which becomes part of the culture in the long run. Poverty and lack of access in the area drove its people to rely on self-medications explicating the prevalence of parasantigwar in the locale as well. Therefore, the emergence of the parasantigwar in the area was brought by passing of culture itself, and experiences on indigence and limitations of access.

Whichever is the reflection of the truth, these grounds connote that its people are resourceful in finding ways to augment their restrictions brought by life setbacks or perpetuation of a practice which shaped their cultural identity.

\section{Conclusion}

The study concluded the richness of the locale's culture on the practices and its preservation of folk healing beliefs. Grounding the life experiences of the parasantigwar led to two major foundations on the acquisition of folk healing practices; apprenticeship and life setbacks. This shows that family, as an immediate environment, plays a significant role in the development and motivation of learning the skill in folk healing. In addition, the body of literature failed to record the role of life setbacks as a motivator to initiate a cultural practice. This fills the gap between cultural anthropology and dynamics on the acquisition of cultural practice by life setbacks. The study concluded that the acquisition of folk healing practices was shaped by the immediate environment, family, as a motivator of the practice.

\section{Recommendations}

Though the study has successfully grounded the experiences of parasantigwar in Cagraray island on becoming a folk healer, certain recommendations need to be considered 
to further testify the result of the current study. An ethnography research may be conducted in other islands surrounding the Cagraray. This will be helpful in tracing the origin of healing practices since reports noted similarities in the healing methods across the area. Also, dichotomization of the folk healing practices need to be analyzed like the use of herbs, minerals, animals, and prayers in treating the illnesses. A study on relationship between folk healing practices and religion is also recommended since the healing practices were primarily founded on prayers and beliefs in supernatural forces.

\section{Acknowledgement}

The researcher acknowledges Dr. Dolores Laguilles for the mentorship and guidance on the development of the original dissertation from which this study was obtained. Also, to the members of the panel, Dr. Lorna Miña, Dr. Oscar Landagan, Dr. Al Besmonte, Dr. Alma Banua, and Dr. Ma. Teresa Mirandilla for the inputs in the original dissertation. The researcher is also fully indebted to PED, Provincial Unit of Albay thru Dr. Roman Chamberlaine Zuñiga for the funding assistance (GRASSP) of the original dissertation. Gratitude is also expressed to Mr. Fred Sambajon, Mr. Gerome Basilla, Ms. Celine Pajera, and Ms. Paula Rose Bibon who made significant contributions in the development and publication of the paper.

\section{The Author}

Michael B. Bibon is a science and research teacher at Cawayan National High School in the Cagraray island, Philippines. He earned his doctoral degree at Bicol University Graduate School. Serving as a teacher-writer in science, he also served as coach in developing science investigatory projects.

\section{References}

[1]. Andrade, C. (2009). Prayer and Healing: A Medical and Scientific Perspective on Randomized Controlled Trials. Indian Journal of Psychiatry. 51 (4). DOI: 10.4103/0019-5545.58288

[2]. Aping, M. (2016). History of Medicine in the Philippines. Retrieved from http://www.marvin-aping.com/index.php/en/history-of-healing.

[3]. Apostol, V.J. and Baet, P.A. (2007). Philippine Healing Arts. Batangas City: Steven K. Dowd. Retrieved at https://www.google.com/url?sa=t\&source=web\&rct=j\&url=https://www.usadojo.com/wp-content/uplo ads/2017/02/fma-Special-Edition_Philippine_Healing-Arts.pdf\&ved=2ahUKEwiS5K30wqPyAhXXfX AKHSkgA5QQFnoECA0QAg\&usg=AOvVaw3pOcnA9QOI7wL4G8oU48mK

[4]. Bacacay, Albay Profile. (n.d.). PhilAtlas.com. Retrieved at https://www.google.com/search?q=bacacy+albay+profile\&oq=bacacy+albay+profile\&aqs=chrome..69i 57.4089j0j4\&client=ms-android-oppo-rev1\&sourceid=chrome-mobile\&ie=UTF-8.

[5]. Berdon, Z., Ragosta, E., Inocian, R., Manalag, C., and Lozano, E. (2016). Unveiling Cebuano Traditional Healing Practices. Asia Pacific Journal of Multidisciplinary Research. 4 (1). Retrieved at https://www.semanticscholar.org/paper/Unveiling-Cebuano-Traditional-Healing-Practices-Berdon-Ragost a/40794888220714bcfc256966f313a42e2677fa33

[6]. Bibon, M. (2021). Indigenous Medicinal Plants and Practices in Cagraray Island: Resources for Culture-Based Lessons in Biology. Journal of Education. https://doi.org/10.1177/0022057420988703

[7]. Brazier, Y. (2018). What was ancient Egyptian medicine like? Retrieved at https://www.medicalnewstoday.com/articles/323633

[8]. Bronfenbrenner, U. (1979). The Ecology of Human Development. Harvard University Press. Cambridge, MA: Folklore Associates, Inc.

[9]. Cerio, C. (2020). Albularyo Folk Healing: Cultural Beliefs on Health Management in Partido District, Camarines Sur, Philippines. Journal of Southeast Asian Studies. 25 (1). DOI: 10.22452/jati.vol25no1.11 
[10]. Chang, L., Mak, M., Li, T., Wu, B., Chen, B., and Lu, H. (2011). Cultural Adaptations to Environment Variability: An Evolutionary Account of East-West Differences. Educational Psychology Review. 23 (1), 99-129. DOI:10.1007/s10648-010-9149-0

[11]. Cvetanovska, J. (2002). Near-Death Experience as the Entrance to the Supernatural. VII (Svrljig): 117-122.

[12]. Fernando, K. and Fermin, M.O. (2008). The Paraphernalia Associated to Traditional Healing Practices of San Miguel Island, Tabaco City. Unpublished Master's Thesis. Daniel B. Pena Memorial Colleges Foundation.

[13]. Field, M. (2019). Traditional Medicine in Underdeveloped Communities: A Vital Income Source. Borgen Magazine. Retrieved https://www.borgenmagazine.com/traditional-medicine-in-underdeveloped-communities/

[14]. Fouad, N., Kim, S., Ghosh, A., Chang, W., and Figueiredo, C. (2015). Family Influence on Career Decision Making. Journal of Career Assessment. 24 (1). DOI: 10.1177/1069072714565782.

[15]. Gilani, A.H., (2005) Trends in Ethnophramacology. J Ethnopharmacol. 100 (1-2). DOI: 10.1016/j.jep.2005.06.001.

[16]. Goldberg, B.D. (2013). Poverty, Wealth, and how Traditional Medicine Would Benefit the United States. Independent Study Project Collection. https://digitalcollections.sit.edu/isp_collection/1628

[17]. Goldstein, K. (1964). A Guide for Field Workers in Folklore. Folklore Associates. ISBN 0810350009

[18]. Handloff, R. (1982). Prayers, Amulets, and Charms: Health and Social Control. Cambridge University Press. 25 (2/3). https://doi.org/10.2307/524216

[19]. Hartzell, S. (2019). The Needs Theory: Motivating Employees with Maslow's Hierarchy of Needs. Study.com.

https://study.com/academy/lesson/the-needs-theory-motivating-employees-with-maslows-hierarchy-ofnee ds.html

[20]. Labastida S.C. TRADISYUNAL NGA PAMULONG: A Rationale on the Persistence of Faith Healing Practices in Miagao, Iloilo. ResearchGate. Retrieved at https://www.researchgate.net/publication/303899461, 2016

[21]. Lamon, N., Neumann, C., Gruber, T, and Zuberbuhler, K. (2017). Kin-based Cultural Transmission of Tool Use in Chimpanzees. Behavioral Ecology, 3(4). DOI:10.1126/sciadv.1602750

[22]. Larsen, A.L., Salamoonsen, A., Kristoffersen, A.E., and Stub, T. (2018). "The Prayer Circles in the Air": A Qualitative Study About Traditional Healer Profiles and Practice in Northern, Norway. International Journal of Circumpolar Health. 77 (1). DOI: 10.1080/22423982.2018.1476638

[23]. Lerman, R. (1967). Witchcraft and Sorcery: Treatment and Prevalence in Sorsogon, Bicol. Unpublished Master's Thesis. Bicol Univeristy.

[24]. McLeod, S. (2020). Maslow's Hierarchy of Needs. Simply Psychology. Retrieved at https://www.simplypsychology.org/maslow.html

[25]. Mercado, L. (1988). Power and Spiritual Discipline among Philippine Folk Healers, Melanesian Journal of Theology, 4(2), 51-63.

[26]. Murphy, K., DPE, CAPE, and Herzog, T. (2015). Sociocultural Factors that Affect Chewing Behaviors Among Betel Nut Chewers and Ex-Chewers on Guam. Hawaii J Med Public Health. 74 (12). Retrieved at https://www.ncbi.nlm.nih.gov/pmc/articles/PMC4675366/

[27]. Peprah, P. Gyasi, R., Adjei, P., Duah, W., Abalo, E., and Kotei, J. (2018). Religion and Health: Exploration of Attitudes and Health Perceptions of Faith Healing Users in Urban Ghana. BMC Public Health. https://bmcpublichealth.biomedcentral.com/articles/10.1186/s12889-018-6277-9

[28]. Peterski, V. (2008). The Secret Knowledge of Folk Healers in Macedonian Traditional Culture. FOLKLORICA 2008, Vol. XIII

[29]. Pocs, E. (1999). Between the Living and The Dead: A perspective on Witches and Seers in the Early Modern Age. Budapest: CEU Press.

[30]. Pocs, E. (2005). Possession Phenomena, Possession Systems. Some East-Central European Examples in Communicating with the Spirits. Demons, Spirits, Witches, ed. Vol.1. Budapest-New York: CEU Press. 84-151.

[31]. Renato, R. (2003). Beliefs and Traditions in the Use of Amulets of Folk Healers in Guinobatan, Albay. Unpublished Master's Thesis. Bicol University.

[32]. Richerson, J. (2005). Not by Genes Alone: How Culture Transformed Human Evolution. Boyd, Robert 1948-. Chicago: University of Chicago Press. ISBN 978-0226712840. OCLC 54806438

[33]. Roostin, E. (2018). Family Influence on the Development of Children. Primary Edu- Journal of Primary Education 2 (1):1. DOI:10.22460/pej.v1i1.654. 
[34]. Santoro, F.R. and Albuquerque, U.P. (2020). Evolutionary Aspects that Guide the Cultural Transmission Pathways in Local Medical System in Northeast Brazil. Heliyon. 6 (6).https://doi.org/10/1016/j.heliyon.2020.e04109

[35]. Saydoven, A. (2009). Filipino Traditional Medicine. Retrieved March 29, 2016 from http://www.scribd.com/doc/22046305/Filipino-Traditional-Medicine-report\#scribd, 2009

[36]. Sequiera de Figueiredo, C.R. and Dias, F.V. (2012). Families: Influences in Children's Development and Behaviour, From Parents and teachers' Point of View. Psychology Research. 2 (12): 693-705. https://www.google.com/url?sa=t\&source=web\&rct=j\&url=https://files.eric.ed.gov/fulltext/ED539404. pdf\&ved=2ahUKEwiRr-uF16HyAhUQFogKHdT8DeYQFnoECCAQAg\&usg=AOvVaw1IddNayBGL mjvKfQBZyPqD\&cshid=1628434469678

[37]. Stuart, G. U. (n.d.). Anting-anting. Philippine Alternative Medicine. Retrieved at http://www.stuartxchange.com/AntingAnting.html

[38]. Taylor, M.J \& Thoth, C.A. (2011). Cultural Transmission. Encyclopedia of Child Behavior and Development. Springer. https://doi.org/10.1007/978-0-387-79061-9_755

[39]. Thwaite, A. (2019). A History of Ten Amulets in Ten Objects. Spring 2019 (11). http://dx/doi.org/10.15180/191103

[40]. Vrazinovski T.(1998). Folk Methodology of the Macedonian People. Prilep-Skopje.

[41]. Wood, L., Kendal, R., and Flynn, E. (2012). Context-Dependent Model-based Biases in Cultural Transmission. Evolution and Human https://doi.org/10.1016/j.evolhumanbehav.2011.11.010.

[41]. Zlatanovic, M. (1989). Charms and Charming Today. Македонски фолклор. 44: 65-68. 


\section{Appendix}

\section{Spiritual/Supernatural Elements}

Anab

Dwende

Engkanto

Kapre

Karaw

Diablo

Tawong Lipod

Ungman
An invisible mystical element believed to cause wounds on the forehead of infants and toddlers.

Dwarves. Minute mystical creatures living in silent places usually not known to people. Destruction and interference of their homes can bring ill to someone.

A supernatural element which can cause malignant effects to patients. Engkanto chooses random victims regardless of age or gender. These elements were thought as skin-changers.

A mystical creature known to exist in tall trees. Indication of its presence is the appearance of a misty cloud which smells like burning cigarette. These are giants who can cause illness to women they express their affection with.

An action of sorcery performed by sorcerers or even folk healers by using black magic to cause harm to someone.

Demons. An entity of possessions

An invisible entity residing on silent places which can cause illness to a person who accidentally struck, bumped, hit, or collided with them

Invisible and ambiguous supernatural forces causing sickness to someone who accidentally disrupts their living spaces.

*Descriptions based from annals of interviewed folk healers 